\title{
Evaluation of effective protein extraction procedure to profile petiole of Moringa oleifera
}

\author{
Zetty Amirah Zulkifli ${ }^{1}$ \& Zaidah Rahmat t,2,3* $^{13^{*}}$ \\ ${ }^{1}$ Department of Biosciences, Faculty of Science, Universiti Teknologi Malaysia, 81310 Johor-Bahru, Malaysia \\ ${ }^{2}$ Chemical Management Unit, University Laboratory Management Centre (PPMU),Universiti Teknologi Malaysia, 81310 Johor-Bahru, Malaysia \\ ${ }^{3}$ Institute of Bioproduct Development, Universiti Teknologi Malaysia, 81310 Johor-Bahru, Malaysia \\ *Email: zettyamirah511@gmail.com, zaidahrahmat@utm.my
}

\section{ARTICLE HISTORY}

Received: 08 January 2020

Accepted: 09 March 2020

Published: 19 April 2020

\section{KEYWORDS}

Moringa oleifera

petiole

1D SDS-PAGE

protein profiling

\section{GUEST EDITOR}

Dr. Nyuk Ling Ma

Universiti Malaysia Terengganu

\section{ABSTRACT}

Moringa oleifera is widely known as multipurpose tree since all of its parts confer multiple functions. The leaf is highly favourable among consumers while the petiole is mostly wasted. There are numerous studies on the flavonoid and antioxidant property of the stem and twig. However, study on the petiole has never been done. There-upon, this study was conducted to develop protein profiling of the petiole. In this study, 6 different protein extraction methods were tested on the fresh petiole before its protein quantity and quality were checked via Bradford assay and Sodium Dodecyl Sulfate Polyacrylamide Gel Electrophoresis (SDS-PAGE) respectively. The in-solution digestion was then done prior to LC-MS/MS analysis. The protein electrophoretic pattern from the SDS-PAGE proves that method 6 using Tris $\mathrm{HCl}$ buffer with incorporation of dithiothreitol (DTT) and phenylmethylsulfonyl fluoride (PMSF) confers the best quality of protein. It produced the highest number of visible individual bands compared to other methods. Meanwhile, 93 proteins were successfully identified via LCMS analysis where the protein, signal response and carbohydrate metabolism categories confer the highest percentage. High quality and content of the protein extracted from the petiole including the antioxidant, anticancer and antidiabetic protein identified suggested that consuming this part of the plant could enhance nutrients of human body.

\section{Introduction}

Moringa oleifera (Moringaceae) is globally known by various names including drumstick tree, horseradish tree and even miracle tree (1). Interestingly, this plant is also considered as multipurpose tree as every part of the plant can be harnessed by mankind (2). Moringa offers various pharmacological traits including antioxidant, antidiabetic and antibacterial activities (3-5). The most reported studies and even the mostly consumed parts of this plant are the leaf and seed $(1,6)$. In fact, researchers are investigating the properties stem and activity especially the one associated with health and medicine for the sake of human. The stems contain tannins, flavonoids, steroids and alkaloids (7). Prominently, its crude extract was identified as high potential natural antioxidants $(7,8)$. The petiole part is the underutilized part which is usually wasted by the consumers. However, protein related study on this petiole is less explored. Protein is an essential nutrient for every living organism including human. Hence, its properties and potential role in pharmacological traits is highly anticipated. Even though several studies on the protein extraction from stem and petiole had been found, none of them were associated with Moringa (9, 10). This plant is a well-known multipurpose medicine plant where each plant part confers own benefits. Thus, the protein content of even the petiole part is highly anticipated. The findings of this study will certainly provide an insight to the potential pharmacological properties of the protein content in the petiole revealing its significance in the household use.

\footnotetext{
(c) Zulkifli and Rahmat (2020). This is an open-access article distributed under the terms of the Creative Commons Attribution License, which permits unrestricted use,
} distribution, and reproduction in any medium, provided the original author and source are credited (https://creativecommons.org/licenses/by/4.0/).

To cite this article: Zulkifli ZA, Rahmat Z. Evaluation of effective protein extraction procedure to profile petiole of Moringa oleifera. Plant Science Today. 2020;7(2):214-218. https://doi.org/10.14719/pst.2020.7.2.730 


\section{Materials and Methods}

\section{Plant material}

The fresh petiole of $M$. oleifera was collected in Johor Bahru, Malaysia. Fresh petiole from the first five branches was removed from the branches and separated from the leaves, before it was ground with liquid nitrogen.

\section{Protein extraction}

Six different protein extraction protocol were tested on the fresh petiole of Moringa oleifera. The first protein extraction method used was modified from Azri et al. (10). Firstly, grinding of $100 \mathrm{mg}$ of fresh petiole with liquid nitrogen was done before $1 \mathrm{~mL}$ of $10 \%$ TCA and $0.07 \% \beta$-mercapto-ethanol in cold acetone was added. After vortex and centrifugation at $14000 \mathrm{rpm}, 4{ }^{\circ} \mathrm{C}$ for $15 \mathrm{~min}$, the pellet was then dissolved in SDS sample buffer. While in method 2 which was also modified from Azri et al. (10), $200 \mathrm{mg}$ instead of $100 \mathrm{mg}$ of fresh petiole was ground with liquid nitrogen before 1 $\mathrm{mL}$ of $20 \%$ TCA and $0.07 \% \beta$-mercaptoethanol in cold acetone was added. After vortexed and centrifuged at $14000 \mathrm{rpm}, 4^{\circ} \mathrm{C}$ for $15 \mathrm{~min}$, the pellet was then dissolved in SDS sample buffer. For method 3, the procedure was modified from Azri et al. (10). Firstly, $200 \mathrm{mg}$ of fresh petiole was ground with liquid nitrogen before $1 \mathrm{~mL}$ of $10 \%$ TCA and $0.07 \% \beta$-mercaptoethanol in cold acetone was added. After vortex and centrifugation at 14000 $\mathrm{rpm}, 4^{\circ} \mathrm{C}$ for $15 \mathrm{~min}$, the pellet was then dissolved in SDS sample buffer. Method 4 was done according to the modification in protein extraction procedure from Sun et al. (9). Firstly, grinding 250 $\mathrm{mg}$ of fresh petiole with liquid nitrogen was done before $0.07 \% \quad \beta$-mercaptoethanol in cold acetone was added. After vortex, the sample was sonicated at $160 \mathrm{~W}$ for $30 \mathrm{~min}$. Centrifugation at $14000 \mathrm{rpm}, 4$ ${ }^{\circ} \mathrm{C}$ for $15 \mathrm{~min}$, was then run before the pellet was dissolved in sample buffer. The fifth method was the QB method (11). $250 \mathrm{mg}$ petiole was ground with liquid nitrogen before $1 \mathrm{mlL}$ QB buffer consist of $2 \mathrm{M} \mathrm{KPO}$ (pH 7.8), 0.5 M EDTA, Triton X-100, 80\% $(\mathrm{v} / \mathrm{v})$ glycerol, and $0.1 \mathrm{mM}$ DTT were added. The mixture was then vortexed and centrifuged at $16000 \mathrm{~g}$ in $4{ }^{\circ} \mathrm{C}$ for $15 \mathrm{~min}$. Next, the supernatant was transferred to new tube before it was spun again. The process were repeated until the supernatant was free of debris. Once done, the sample was kept in $-80{ }^{\circ} \mathrm{C}$ until further use. Lastly, method 6 using $100 \mathrm{mM}$ Tris buffer was quite similar to QB method. $250 \mathrm{mg}$ petiole was ground with liquid nitrogen before $1 \mathrm{~mL}$ extraction buffer consisting of $100 \mathrm{mM}$ Tris HCL pH 7.5, $10 \mathrm{mM}$ DTT and $1 \mathrm{mM}$ PMSF were added. The mixture was then vortexed and centrifuged at $16000 \mathrm{~g}$ in $4{ }^{\circ} \mathrm{C}$ for 15 min. Next, the supernatant was transferred to new tube before it was spun again. The process was repeated until the supernatant was free of debris. Once done, the sample was kept in $-80{ }^{\circ} \mathrm{C}$ until further use.

\section{SDS-PAGE analysis and in-solution digestion}

The protein concentration assay using Bradford reagent was done in order to determine the total protein amount and protein yield of the extracted protein. The results were analysed by one-way analysis of variance (ANOVA) by SPSS Statistics software to compare significant differences of the methods. The data were expressed as mean \pm SEM where the difference was considered significant when the $P$ value is less than 0.05 . Lastly, quality of the extracted protein was determined in the means of one-dimensional protein separation (SDS-PAGE) where the protein was separated according to their molecular weight. In order to identify the protein and peptides present in the extracted protein sample, in-solution digestion was performed. Firstly, the protein volume $(50 \mu \mathrm{g})$ was increased to $100 \mu \mathrm{L}$ with $50 \mathrm{mM} \mathrm{NH}_{4} \mathrm{HCO}_{3}$ Next, $5 \mu \mathrm{L} 200 \mathrm{mM}$ DTT (in $100 \mathrm{mM} \mathrm{NH}_{4} \mathrm{HCO}_{3}$ was added to reduce the sample by boiling it for $10 \mathrm{~min}$. followed by incubation at room temperature for 45-60 min. Alkylation was done by adding $4 \mu \mathrm{L} \quad 1 \mathrm{M}$ iodoacetamide to the samples, vortexed, spun briefly and incubated at room temperature for 45$60 \mathrm{~min}$. Then, neutralization of iodoacetamide proceeded by the addition of $20 \mu \mathrm{L} 200 \mathrm{mM}$ DTT, vortexed, spun and incubated at room temperature for 45-60 min. Trypsin digestion was carried out in a ratio of $1: 50$ to $1: 20$ of trypsin to sample where the samples were vortexed and spun briefly prior to overnight incubation at $37{ }^{\circ} \mathrm{C}$. The next day, $2 \%$ $(\mathrm{v} / \mathrm{v})$ formic acid was added to the sample until the $\mathrm{pH}$ reached to $\mathrm{pH} 6.0$ using a pH paper indicator. The samples were then cleaned with C18 Zip Tip (Millipore) by rinsing the tips $5 \mathrm{X}$ each in ACN, $1 \%$ $(\mathrm{v} / \mathrm{v})$ formic acid, samples, and $0.1 \%(\mathrm{v} / \mathrm{v})$ formic acid followed by elution in $10 \mu \mathrm{L} 0.1 \%(\mathrm{v} / \mathrm{v})$ formic $\operatorname{acid} / 50 \%(\mathrm{v} / \mathrm{v}) \mathrm{MeOH}$ and vacuum dried for $15 \mathrm{~min}$. Lastly, the digested sample was sent for LCMS analysis. Prior to LC-MS/MS analysis, the tube was reconstituted with $8 \mu \mathrm{L}$ of $0.1 \%(\mathrm{v} / \mathrm{v})$ formic acid. The analysis was performed using Agilent 1200 HPLC-Chip/MS Interface coupled with Agilent 6520 Accurate-Mass Q-TOF LC/MS using Large Capacity Chip, $300 \AA \AA$, C18, 160 nanoflow enrichment column and $75 \mu \mathrm{m} \times 150 \mathrm{~mm}$ analytical column (Agilent Technologies, CA, USA). The flow rate was set at 0.3 $\mu \mathrm{L} / \mathrm{min}$ and the amount of sample loaded was $1 \mu \mathrm{L}$. The complete run took $47 \mathrm{~min}$ in a gradient system that consists of solvent $\mathrm{A}(0.1 \%(\mathrm{v} / \mathrm{v})$ formic acid in water) and solvent B (90\% (v/v) ACN in water with $0.1 \%(\mathrm{v} / \mathrm{v})$ formic acid). The MS parameter was set at positive ion mode and data acquisition in MS/MS mode with MS/MS scan range of 50 to $3000 \mathrm{~m} / \mathrm{z}$ at a rate of 4 spectra/s and time $250 \mathrm{~ms} / \mathrm{spectrum}$.

\section{Protein identification and functional categorization}

The data obtained was analyzed using PEAKS 7. The software parameter was set accordingly. The spectra were blasted against Uniprot Arabidopsis thaliana database for all the species. The search mode was set as identity, where the MS/MS spectra were compared to the unmodified sequence in the database and variable modification (Carbamidomethylation). Lastly, the identified proteins were classified to their GO biological function by the means of GoMapMan database (http://www.gomapman.org/). 


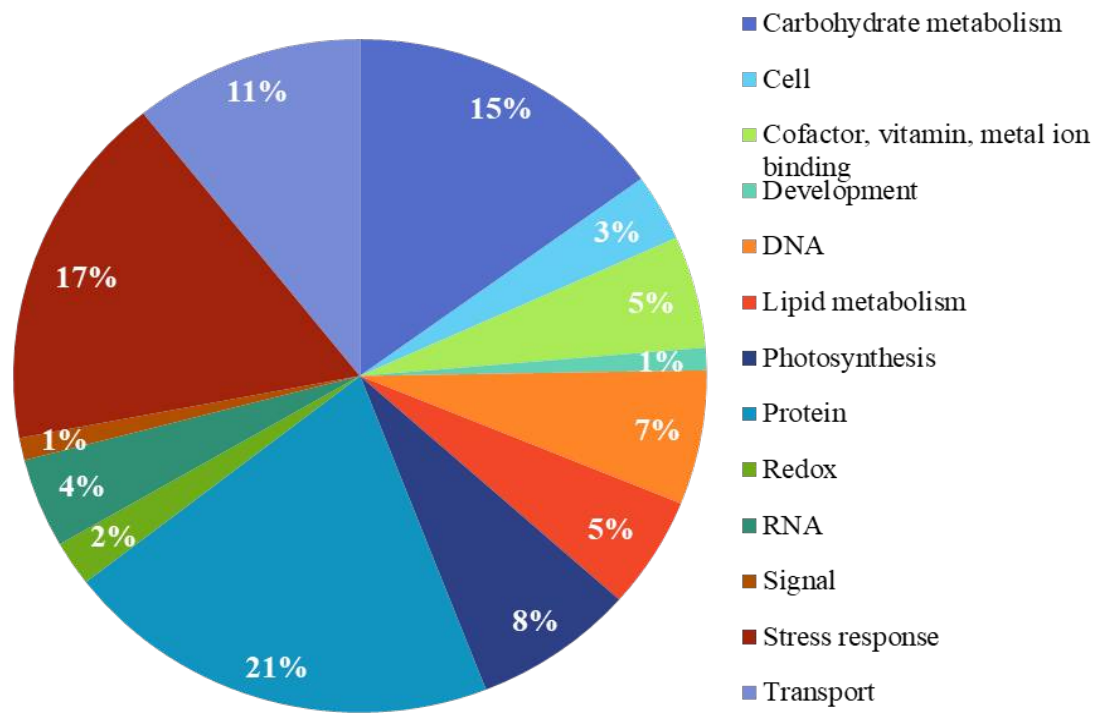

Fig. 2. Functional protein categories of the petiole of Moringa oleifera.

\section{Results and Discussion}

\section{Determination of the best protein extraction method}

Similar protein extraction method used on ginseng and poplar plants were tested out on the petiole of Moringa referred to as methods 1,2 , 3, and 4 . Meanwhile, protein extraction method 5 (QB) and 6 (Tris buffer) were tested out on petiole since these two methods are highly compatible with the leaf of Moringa. Protein quantity of the petiole extracted by using 6 different protocols were quantified via Bradford assay. The final protein concentration, total protein amount and protein yield of the extracted samples were tabulated in Table 1 . The values are means $(n=3) \pm$ SEM where values with different superscript are significantly different at $\mathrm{p}<0.05$.

Table 1. Quantification of Moringa oleifera petiole via Bradford assay. The values represent average \pm SEM $(n=3)$. Protein amount and yield for all methods were statistically significant at $\mathrm{p}<0.05$ using One Way ANOVA

\begin{tabular}{|c|c|c|c|c|}
\hline $\begin{array}{l}\text { Protein } \\
\text { Extraction } \\
\text { Method }\end{array}$ & Extraction buffer & $\begin{array}{l}\text { Wt. } \\
\text { (g) }\end{array}$ & $\begin{array}{l}\text { Total protein } \\
\text { amount }(\mu \mathrm{g}) \\
\pm \text { SEM }\end{array}$ & $\begin{array}{l}\text { Protein } \\
\text { yield }(\mu \mathrm{g} / \\
\mathrm{mg}) \pm \mathrm{SEM}\end{array}$ \\
\hline $\begin{array}{l}\text { Method } 1 \\
\text { (10) }\end{array}$ & $\begin{array}{l}10 \% \text { TCA, } \\
\beta \text {-mercaptoethanol } \\
\text { in acetone }\end{array}$ & 0.1 & $301.95 \pm 10.29$ & $\overline{3.02 \pm 0.1}$ \\
\hline $\begin{array}{l}\text { Method } 2 \\
\text { (10) }\end{array}$ & $\begin{array}{l}20 \% \text { TCA, } \\
\beta \text {-mercaptoethanol } \\
\text { in acetone }\end{array}$ & 0.2 & $69.63 \pm 1.57$ & $0.35 \pm 0$ \\
\hline $\begin{array}{l}\text { Method } 3 \\
\text { (10) }\end{array}$ & $\begin{array}{l}10 \% \text { TCA, } \\
\beta \text {-mercaptoethanol } \\
\text { in acetone }\end{array}$ & 0.2 & $19.89 \pm 1.08$ & $0.1 \pm 0.01$ \\
\hline $\begin{array}{l}\text { Method } 4 \\
\quad(9)\end{array}$ & $\begin{array}{l}\text {-mercapto } \\
\text { ethanol in cold } \\
\text { acetone }\end{array}$ & 0.25 & $55.9 \pm 3.83$ & $0.22 \pm 0.02$ \\
\hline $\begin{array}{l}\text { Method } 5 \\
\text { (11) }\end{array}$ & QB buffer & 0.25 & $1987.28 \pm 33.88$ & $7.95 \pm 0.14$ \\
\hline Method 6 & Tris buffer & 0.25 & $916.03 \pm 82.93$ & $3.66 \pm 0.33$ \\
\hline
\end{tabular}

According to the Table 1, method 5-QB buffer had the highest protein quantity followed by method 6-Tris buffer and the least protein quantity was shown by method 3. On the contrary, based on Fig.1, the bands separation by method 6 (Tris buffer) in one dimensional SDS-PAGE was the best followed by QB buffer while the rest show very light band intensity. The compatibility of the petiole with QB and Tris buffer did resemble the leaf of this plant. In fact, leaf of Moringa also produced the highest protein quantity by QB method while best protein quality was exhibited by the Tris buffer.

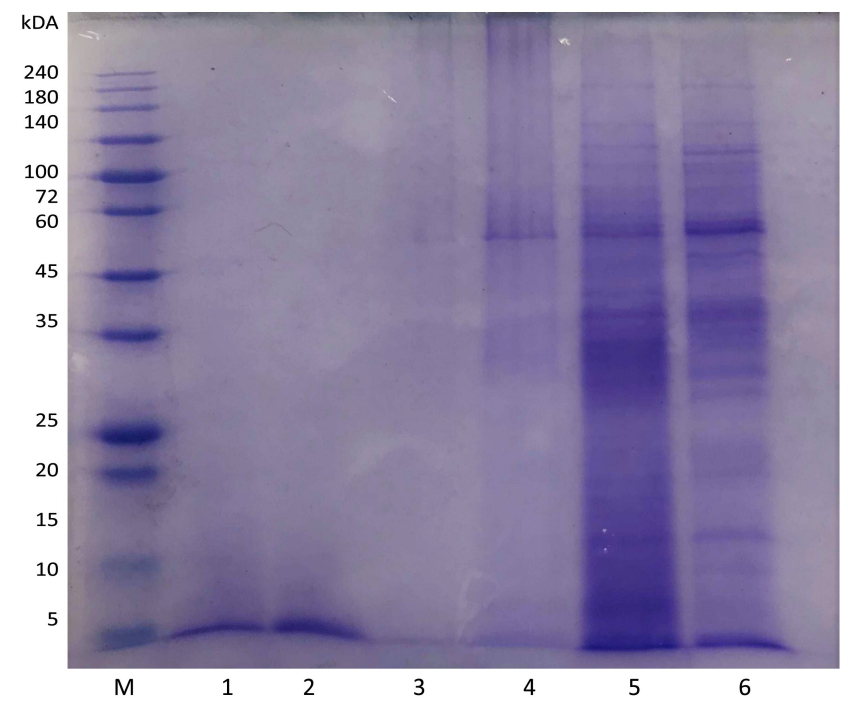

Fig. 1. One dimensional gel electrophoresis of fresh petiole of M. oleifera where protein was loaded at $10 \mu \mathrm{g}$ per well (M: Marker, 1-6: protein extraction methods 1-6).

The presence of DTT and PMSF in the Tris buffer had contributed to a more intense band which reflect the protein quality. DTT for an instance disrupts the disulphide bond of the protein while PMSF plays vital role as protease inhibitor which inhibit degradation of the protein specifically during the extraction process hence enhanced the quality of the extracted protein sample $(12,13)$. In comparison with stem of other plants such as poplar and Korean ginseng, the proteins are best extracted using TCA and acetone precipitation $(9,10)$. TCA and acetone precipitation method is highly suitable and compatible to extract protein from stubborn and recalcitrant plant tissue (14). Similar protein extraction method from the 
ginseng and poplar had been tested out on Moringa's petiole, referred to as methods $1,2,3$, and 4 . However, the results of protein electrophoretic pattern from these methods were very bad with less band intensity. This is probably due to the fact that the stem used in Moringa was the petiole which confers less recalcitrant tissue compared to the ginseng and poplar stem hence extraction methods utilizing TCA and acetone were incompatible with the petiole of Moringa.

\section{Protein profiling analysis}

The data obtained from the LC-MS/MS analysis had successfully identified 125 peptides which represent 93 distinct proteins of the petiole of Moringa. The identified proteins were then categorized according to its function as represented in the Fig. 2. From 93 individual proteins, the highest percentage of $21 \%$ play role in protein function while the least was 1\% which were attributed to the category of development and signal. The second and third highest were the stress response and carbohydrate metabolism with 17 and 15 percentage values respectively. The stress response proteins mostly refer to the plant response towards stress including salt, cold and even free radicals. Meanwhile, carbohydrate metabolism refers to the glycolytic and gluconeogenesis process where aldolase and beta galactosidase were found. Interestingly, antidiabetic proteins including transketolase was also found in the carbohydrate metabolism function. In fact, antioxidant and anticancer proteins such as peroxidase, superoxide dismutase, L-ascorbate peroxidase and glutathione peroxidase were successfully identified in the signal response category.

The pharmaceutical industry is evolving rapidly where the scientists are trying to find ideal replacement for the already established synthetic drugs due to severe drawbacks that it caused. Protein from plant is currently one of the potent alternative since it offers low risk of rejection in spite of its high reproducibility. Diabetic and cancer for instance are the two major cause of death in the world hence its cure is highly anticipated. The transketolase is highly targeted as antidiabetic alternative since it plays key role in pentose phosphate pathway (15). Hence, identification of this protein in the petiole is definitely an insight toward further analysis and application specifically in antidiabetic area.

Furthermore, multiple proteins associated with the antioxidant and anticancer found in the petiole is also adding value to this wasted plant part. Peroxidase, superoxide dismutase, L-ascorbate peroxidase and glutathione peroxidase are well known for its ability to prevent cellular destruction caused by the free radicals and its oxidation process $(16,17)$. While consumers are eagerly buying antioxidants products in the market, this petiole's protein definitely offer nothing less.

\section{Conclusion}

Tris buffer with the incorporation of DTT and PMSF was chosen as the best protein extraction reagent for the petiole of Moringa oleifera. This is according to the protein electrophoretic formation which reflects the quality of the extracted protein. The production of multiple individual bands from the petiole shows high quality content of protein. The leaf of Moringa is highly favourable among consumers for centuries while the petiole is wasted. Hence, the findings from protein profiling analysis suggest that petiole of Moringa should also be consumed by the people since it also offers highly potential medicinal protein such as antidiabetic, antioxidant and anticancer. Indeed, further detailed study on the pharmacological activities such as antioxidant and antidiabetic of this petiole should be conducted to reveal its true potential and benefits in fighting the diseases.

\section{Authors' contributions}

ZAZ conceived and performed the experiment and data analysis. ZR supervised the project. ZAZ and ZR discussed the results and contributed to the writing of the manuscript. Both the authors read and approved the final manuscript.

\section{Acknowledgements}

The authors wish to express their gratitude to the University Teknologi Malaysia and Zamalah scholarship award for the platform to conduct this research.

\section{Conflict of interest}

The authors declare that they have no competing interest.

\section{Ethical statement}

This research was in compliance with ethical standards. This article does not contain any studies with human participants or animals performed by any of the authors.

\section{References}

1. Anwar F, Bhanger M. Analytical characterization of Moringa oleifera seed oil grown in temperate regions of Pakistan. J $\begin{array}{llll}\text { Agric } & \text { Food } & \text { Chem } & \end{array}$ https://doi.org/10.1021/jf0209894

2. Amaglo NK, Bennett RN, Curto RBL, Rosa EA, Turco VL, Giuffrida A. et al. Profiling selected phytochemicals and nutrients in different tissues of the multipurpose tree Moringa oleifera L., grown in Ghana. Food Chem 2010;122(4):1047-54. https://doi.org/10.1016/j.foodchem.2010.03.073

3. Dolly J, Rai PK, Amit K, Shikha M, Geeta W. Effect of Moringa oleifera Lam. leaves aqueous extract therapy on hyperglycemic rats. J Ethnopharmacol 2009;123(3):392-96. https://doi.org/10.1016/j.jep.2009.03.036

4. Kamath N, Swaminathan R, Desai N. Antibacterial activity of Indian medicinal plant- Moringa oleifera against MRSA and Klebsiella Spp. (ESBL) which are commonly isolated bacteria in hospital environments. Int J Adv Res. 2016;2(8):515-17

5. Torres C, Sanchez J, Osorio H, Sinagawa G, Aguirre A, Gutiérrez D. Moringa oleifera: Phytochemical detection, antioxidants, enzymes and antifugal properties. Int J Exp Bot. 2013;82:193 202

6. Ilyas M, Arshad M, Saeed F, Iqbal M. Antioxidant potential and nutritional comparison of moringa leaf and seed powders and their tea infusions. J Anim Plant Sci. 2015;25:226-33 
7. Kumbhare MR, Guleha V, Sivakumar T. Estimation of total phenolic content, cytotoxicity and in-vitro antioxidant activity of stem bark of Moringa oleifera. Asian Pac J Trop Dis. 2012; 2(2):144-50. https://doi.org/10.1016/S2222-1808(12)60033-4

8. Atawodi SE, Atawodi JC, Idakwo GA, Pfundstein B, Haubner R, Wurtele G, Owen RW. Evaluation of the polyphenol content and antioxidant properties of methanol extracts of the leaves, stem and root barks of Moringa oleifera Lam. J Med Food. 2010;13(3):710-16. https://doi.org/10.1089/jmf.2009.0057

9. Sun LW, Ma PT, Li DN, Lei XJ, Ma R, Qi C. Protein extraction from the stem of Panax ginseng CA Meyer: a tissue of lower protein extraction efficiency for proteomic analysis. Afr J Biotechnol. 2011;10(21):4328-33.

10. Azri W, Ennajah A, Jing M. Comparative study of six methods of protein extraction for two-dimensional gel electrophoresis of proteomic profiling in poplar stems. Can J Plant Sci. 2013; 93:895-901. https://doi.org/10.4141/cjps2013-113

11. Ni M, Dehesh K, Tepperman JM, Quail PH. GT-2: in vivo transcriptional activation activity and definition of novel twin DNA binding domains with reciprocal target sequence selectivity. Plant Cell. 1996;8(6):1041-59. https://doi.org/10.1105/tpc.8.6.1041

12. Westermeier R, Naven T, Höpker HR. Proteomics in Practice: A Guide to Succesful Experimental Design. John Wiley \& Sons 2008;2:67. https://doi.org/10.1002/9783527622290
13. Maranho RC, Benez MM, Maranho GB, de Azevedo Fernandes VN, Gonela A, Mangolin CA. da Silva Machado MFP. Extraction of total protein from axillary buds of sugarcane (Saccharum spp.) for proteomic Analysis. Sugar Tech. 2018;20(1):95-99. https://doi.org/10.1007/s12355-017-0520-Z

14. Carpentier SC, Witters E, Laukens K, Deckers P, Swennen R, Panis B. Preparation of protein extracts from recalcitrant plant tissues: An evaluation of different methods for twodimensional gel electrophoresis analysis. Proteomics. 2005;5: 2497-07. https://doi.org/10.1002/pmic.200401222

15. Horecker BL. The pentose phosphate pathway. J Biol Chem. 2002;277(50):47965-71. https://doi.org/10.1074/jbc.X200007200

16. Caverzan A, Passaia G, Rosa SB, Ribeiro CW. Lazzarotto F, Margis-Pinheiro M. Plant responses to stresses: role of ascorbate peroxidase in the antioxidant protection. Genet Mol Biol. 2012;35(4):1011-19. https://doi.org/10.1590/S141547572012000600016

17. Battin EE, Brumaghim JL. Antioxidant activity of sulfur and selenium: a review of reactive oxygen species scavenging, glutathione peroxidase and metal-binding antioxidant mechanisms. Cell Biochem Biophys. 2009;55(1):1-23. https://doi.org/10.1007/s12013-009-9054-7 